Florida International University FIU Digital Commons

11-10-1998

\title{
An assessment of nurses' knowledge and attitudes toward patients with sickle cell disease
}

Marie Osline Etienne

Florida International University

DOI: $10.25148 /$ etd.FI15101322

Follow this and additional works at: https://digitalcommons.fiu.edu/etd

Part of the Nursing Commons

\section{Recommended Citation}

Etienne, Marie Osline, "An assessment of nurses' knowledge and attitudes toward patients with sickle cell disease" (1998). FIU Electronic Theses and Dissertations. 3281.

https://digitalcommons.fiu.edu/etd/3281

This work is brought to you for free and open access by the University Graduate School at FIU Digital Commons. It has been accepted for inclusion in FIU Electronic Theses and Dissertations by an authorized administrator of FIU Digital Commons. For more information, please contact dcc@fiu.edu. 
FLORIDA INTERNATIONAL UNIVERSITY

Miami, Florida

AN ASSESSMENT OF NURSES' KNOWLEDGE

AND ATTITUDES TOWARD PATIENTS

WITH SICKLE CELL DISEASE

A thesis submitted in partial fulfillment of the

requirements for the degree of

\section{MASTER OF SCIENCE}

in

NURSING

by

Marie Osline Etienne 
To: Dean DeLois P. Weekes

College of Health Sciences

This thesis, written by Marie Osline Etienne, and entitled An Assessment of Nurses? Knowledge and Attitudes Toward Patients with Sickle Cell Disease, having been approved in respect to style and intellectual content, is referred to you for judgement.

We have read this thesis and recommend that it be approved.

William J. Keppler

Marjorie T. Burkett

Luz S. Porter, Major Professor

Date of Defense: November 10, 1998

The thesis of Marie Osline Etienne is approved.

Dean DeLois P. Weekes College of Health Sciences

Dean Richard L. Campbell Division of Graduate Studies

Florida International University, 1998 
(C) Copyright 1998 by Marie Osline Etienne

All rights reserved. 


\section{DEDICATION}

I dedicate this thesis to my mother, Lucienne Louis Elie, my Husband Marc-Arthur Philippe-Auguste, my daughter Krystal and my son Marc-Anthony. They have provided the driving force from the beginning to the completion of this work. Without their understanding, patience, support, and most of all, love, the completion of this work would not have been possible. 


\section{ACKNOWLEDGMENTS}

I wish to thank the members of my committee, Dr. Porter, Dr. Keppler, and Dr. Burkett for their guidance, patience, understanding, and support. This research would not have been possible without the support of many other people. Respectfully, I would like to thank Dr. Luz S. Porter for helping me during this most intensified period in my life. A special thanks also to Dr. Cynthia Fletcher for all her encouragement during this process. Special thanks must be given to my sisters, brother, and friends who believed in me. I would also like to thank the two hospitals and Florida International University for providing me with data collection sites. 


\section{ABSTRACT OF THE THESIS \\ AN ASSESMENT OF NURSES' KNOWLEDGE LEVEL AND ATTITUDES TOWARD PATIENTS \\ WITH SICKLE CELL DISEASE}

by

Marie Osline Etienne

Florida International University, 1998

Miami, Florida

\section{Professor Luz S. Porter, Major Professor}

This descriptive comparative, correlational study examined nurses' knowledge and attitudes towards patients with sickle cell disease (SCD). The literature suggests that SCD patients are inadequately managed by nurses, resulting in unnecessary suffering, delayed treatment, and prolonged hospitalization. The study was conducted on a convenience sample of 109 registered nurses (RNs) working in southeast Florida. The data, collected via self-administered questionnaires using the Nurses Knowledge Base Inventory (Lorenzi, 1993) and the Sickle Cell Disease Attitude Questionnaire, were analyzed by descriptive and inferential statistics. Knowledge was not found to be correlated with attitude. A perplexing finding was the inverse relationship between education level and attitude $(r=.23, p=.015)$. Ethnicity was not a differentiating factor in nurses SCD attitude scores, however, there was a strong trend showing that Blacks were the least positive in SCD attitude among the four ethnic groups studied. Formal education alone may not be sufficient in gaining better knowledge and understanding about SCD. Appropriate interventions might be achieved when nurses are knowledgeable about SCD and possess a positive attitudes toward patients with SCD. 


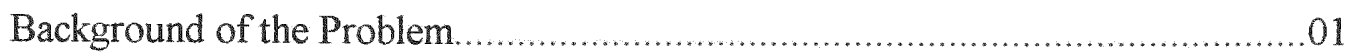

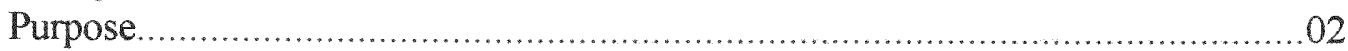

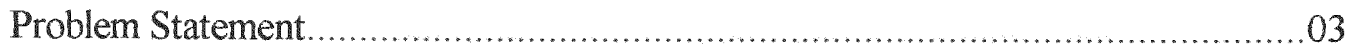

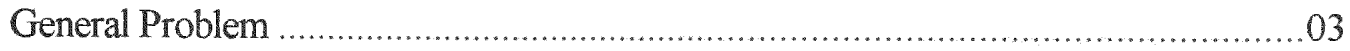

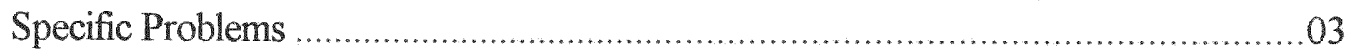

Definition of Terms

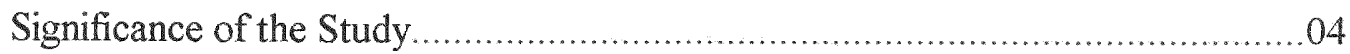

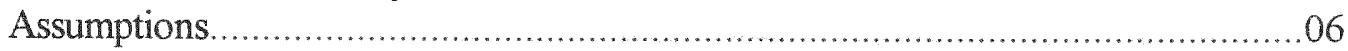

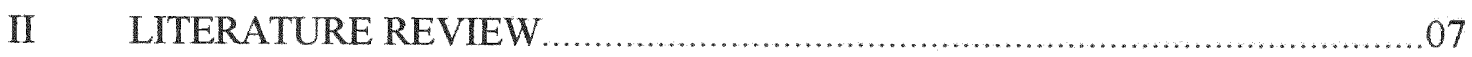

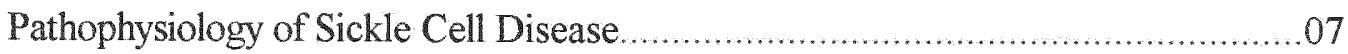

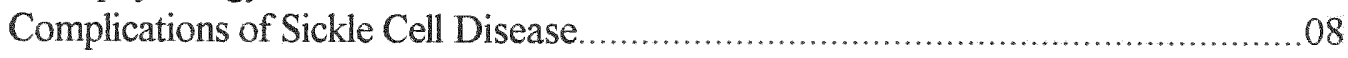

Knowledge Level and Attitudes................................................................ 12

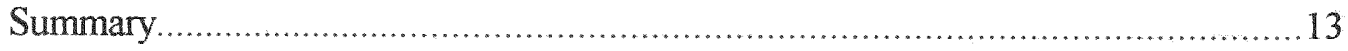

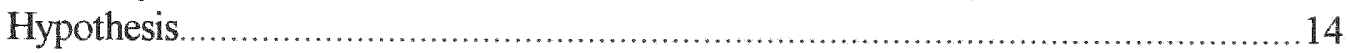

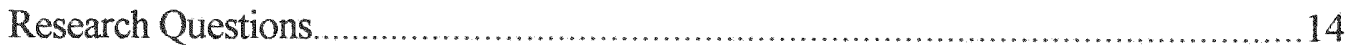

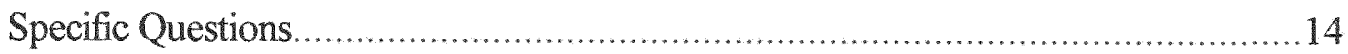

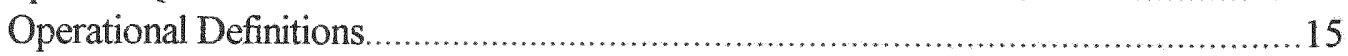

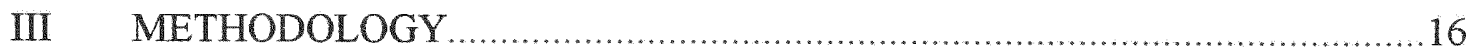

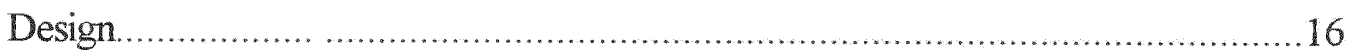

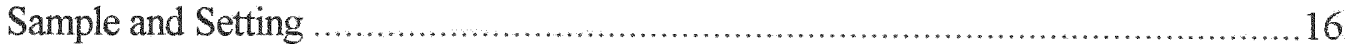

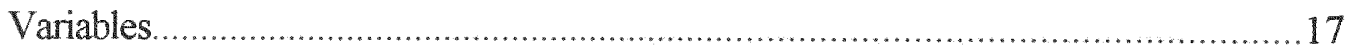

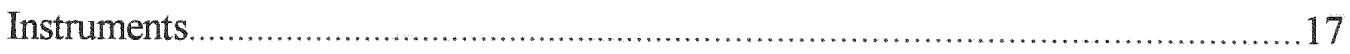

Data Collection and the Protection of Human Subjects....................................... 18

Method of Data Analysis........................................................................... 19

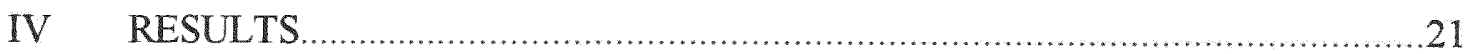

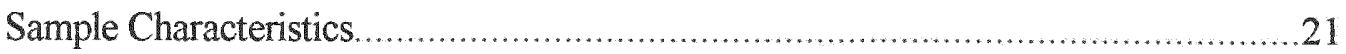

Findings Relating to the Research Questions................................................25

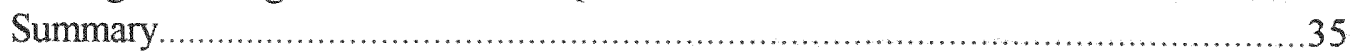


V DISCUSSION.

Discussion of Findings, Implications. Limitations, and Recommendations................36

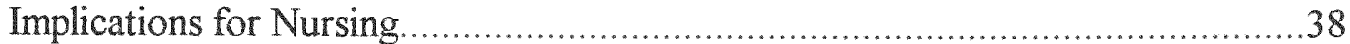

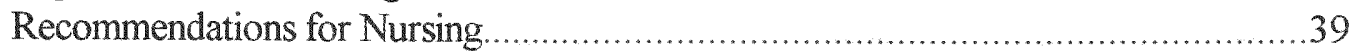

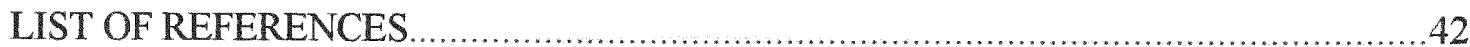

APPENDIXES 


\section{LIST OF TABLES}

TABLE

PAGE

TABLE 1 Frequency Distribution of the Sample by Personal Attributes .23

TABLE 2 Frequency Distribution of the Sample by Education and Professional Experience

TABLE 3 Knowledge Base Inventory Item Correct Response Scores, by Study Site ......27

TABLE 4 Sickle Cell Disease Attitude Scores, by Study Site .......................................30

TABLE 5 Descriptive Analysis o Attitude Scores, by Ethnicity ...................................33

TABLE 6 One-Way ANOVA Analysis of Attitude Scores, by Ethnicity ........................33

TABLE 7 Relationships Among Knowledge, Attitude, Education and Experience .........34 


\section{CHAPTER I}

\section{Introduction}

\section{Background of the Problem}

Sickle Cell Anemia has been described as the most common genetic disease, affecting 1 in 500 blacks (Platt, 1997). Sickle Cell Anemia is a world wide health problem, affecting many races, countries and ethnic groups. This blood dyscrasia is a lifelong disease with complications of varying intensity and severity. The World Health Organization (WHO, 1996) estimated that each year more than 250,000 babies are born worldwide with this inherited blood cell disorder, which causes red blood cells to elongate and clog arteries. Chronic pain and life-threatening infections may result from the illness. Every possible effort should be made to avoid potentially harmful outcomes for people with Sickle Cell Disease (Whitten, 1989).

One theory proposes that sickle cell anemia originated in Africa and, through the slave trade, spread to South America, North America and Europe. Another theory suggests the illness began in the Middle East and spread from there. Although in the United States sickle cell disease is most commonly found in persons of African ancestry, it also affects other population, including those of Mediterranean, Caribbean, South and Central America, East India, and Arabian ancestry (Gribbons, Zahr, \& Opas, 1995).

Sickle Cell Anemia is the most common form of the sickle cell disease, affecting more than 50,000 Americans. The estimated prevalence of Sickle Cell Anemia is African-American live births 1:375 (approximately $8 \%$ of the African-American population carry the Bs globin gene, the Sickle cell trait). Hgb SC disease has an 
estimated prevalence of 1:835 African-American live births, and the sickle cell beta-Thalassemia disorders have an estimated prevalence of 1:1667 (Woods, 1994).

Woods (1994) indicated that health perceptions and medical care opinions received more adverse ratings among sickle patients than in patients with other chronic diseases. Anuonwu (1996) further indicates that because of negative attitudes, affected individuals may often be viewed as "difficult" and the inadequate treatment available for the severe painful crisis add to the problem of both the patients and nursing staff. An underlying irritant for many patients and nurses are the negative attitudes that may exist between them. Nurses may be wary of patients with sickle cell disorders for a variety of reasons. They may not have received adequate education about the condition, be anxious to prevent drug dependency and may also harbor underlying racists views. In addition, there will also be resentment and fear of verbal abuse they may expect from some patients (Anionwu, 1996). Anionwu (1996) stipulates that there is a danger that the development of such tensions may become so severe that the nurse uses avoidance techniques. These may have serious, even fatal consequences in the event of life-threatening complications that can suddenly develop in patients with sickle cell disorders. Platt (1997) indicate that it is essential for healthcare professionals to recognize that patients admitted frequently with painful crises are at a higher risk of early death. Vital clues of a worsening anemia, cardiac failure or respiratory distress may be missed if regular nursing observations have not been carried out (Anionwu 1996).

\section{Purpose}

The purpose of this study was to examine the nurses' knowledge level of Sickle 
Cell Anemia and how their knowledge affected their attitudes toward patients with sickle cell disease. With so much emphasis being placed on decreased length of hospitalization stay, cost effective care, cost containment, managed care, taxpayers paying for the cost of patients with sickle cell disease, one would expect a broader understanding of the disease by nurses than previous literature indicates. The outcome of this sought to aid in increasing the understanding of nurses' knowledge base and attitudes. From an ethical standpoint and quality care, adequate knowledge and more appropriate attitudes and interventions could potentially result in patient satisfaction, decreased complications, cost containment, and community satisfaction.

\section{Problem Statement}

\section{General Problem:}

What is the knowledge level of nurses concerning sickle cell disease (SCD) and their attitudes toward patients with SCD patients specific problems?

Specific Problems:

1. To what extent are nurses knowledgeable about SCD?

2. What kind of attitude do nurses have towards patients with SCD?

3. What is the relationship between nurses ${ }^{6}$ knowledge concerning sickle cell disease and their attitudes toward SCD patients?

4. To what extent are nurses' attitudes toward SCD patients influenced by sociodemographic factors, namely,
a. Ethnicity
b. Gender 

c. Age
d. Education
e. Nursing Experience

\section{Definition of Terms}

For the purpose of this study terminology were defined as follows:

Attitude: A manner of acting, feeling or thinking about something that shows one's disposition, opinion (Webster 1996).

Knowledge: A clear and certain perception of something, the state of knowing, awareness, or understanding (Webster 1996).

Knowledge level about SCD: The breadth and depth of accurate information concerning SCD, which include pathophysiology, management, mode of transmission, complications and others.

Nurse: A registered nurse (RN) working in a hospital or actively pursuing an advanced nursing degree such as a BSN or an MSN.

Sickle Cell Disease: A hereditary blood disorder that affects the oxygen-carrying component of blood, the red blood cells, causing them to elongate and then clog arteries (Woods, 1994).

\section{Significance of the Study}

There is an extensive amount of information to be understood of sickle cell disease by nurses. Previous studies done on nurses' knowledge of pain management in sickle cell patients have shown a less than optimal understanding of effective approaches. Sickle Cell Disease is a lifelong illness, more emphasis on nurses' knowledge will influence their 
decisions and critical thinking in their approaches when caring for patients with Sickle Cell Disease. Greater emphasis has been placed on education through the literature that nurses need to have a better understanding on the management of patients with Sickle Cell Disease and any other factors that may be associated with their approaches. Some of those factors may be related to age, sex, race, culture, and any other forms of attributes.

Nightingale (1969) noted that one of the primary functions of nursing is to relieve or eliminate sources of problems that might affect the patient's state of wellness. She believed that the main focus of nursing is to provide a peaceful state for the body to heal; therefore by controlling the external environment, notably ventilation, warmth, odor, noise, and light, healing would take place. As we move into the 21 st century, nurses will be faced with many challenges, and some of these challenges will be placed on cost-effectiveness, cost containment, managed care. But, nurses must not let these challenges affect the nurses' methods and approaches when caring for patients with sickle cell disease. The outcome of this study may identify gaps of knowledge among nurses caring for patients with SCD, increase awareness of sickle cell disease, increase nurses' knowledge base of SCD, develop more effective attitudes and approaches toward patients with SCD. Specific guidelines and protocols for patients with SCD may be established and positive outcomes if appropriate knowledge is achieved regarding $\mathrm{SCD}$ will be indicated. Emphasis on continuing education for nurses caring for patients with SCD will be discussed.

Earles (1989) indicates that nurses must assume the role of an advocate, educator, case manager after patients have been diagnosed with Sickle Cell Disease. The nurse has 
one of the major responsibility for knowing about the disease itself; how to approach each patients; using appropriate management and interventions of Sickle Cell Disease.

Knowledge may be the best defense when caring for patients with SCD.

Assumptions

The assumptions of this study were:

1. Knowledge can influence one's attitude and behaviors.

2. Attitudes and behaviors can be influenced by a lack of information, and personal attributes.

3. Attitudes and behaviors are influenced by culture, personal, sociologic, and environmental factors.

4. Knowledge of Sickle Cell Disease may influence nurses' attitudes and behaviors toward patients with Sickle Cell Disease. 


\section{CHAPTER II}

\section{Literature Review}

Sickle Cell Disease (SCD) is a term used to describe different hemoglobinopathies: sickle-beta Thalassemia, hemoglobin SC disease, and Sickle Cell Anemia (Lisak, 1992). It is an inherited blood condition common among, but not confined to, people of equatorial African ancestry (Serjeant, 1997). Selekman (1993) indicates that sickle cell anemia is the most common form of the disease, and it affects 1 in 375 African-American infants.

Although sickle cell is commonly found in persons of African-American ancestry, it also affects other populations.

Serjeant (1997) explicates that Sickle Cell Disease was first recognized in people in West African ancestry, giving rise to the common misconception that the illness was confined to this group. The sickle cell trait occurs in 10-30\% of people in Equatorial Africa but is infrequent in North and South Africa. The HBO gene, the gene for sickle cell hgb, is now known to be more widespread, occurring in the Mediterranean in Sicily and other parts of Southern Italy, northern Greece, Turkey along south-east coasts, the north African coast, in Saudi Arabia especially the eastern province, and throughout central India. The people with the sickle cell trait have a relative resistance to malaria so are more likely to survive, breed, and pass on their genes (Serjeant, 1997).

\section{Pathophysiology of Sickle Cell Disease}

Platt (1997) states that there are two cardinal pathophysiologic features of sickle cell disorders: chronic hemolytic anemia and vaso-occlusion (which result in ischemic tissue injury). Hemolytic anemia may be related to repeated cycles of sickling and 
unsickling, which interact to produce irreversible red cell membrane changes, red cell dehydration, and erythrocyte destruction. The underlying problem that causes the occurrence of the sickle cell hemoglobin at the molecular level is the substitution of valine on each beta chain in place of glutamic acid (Martinelli, 1991). "The gene for sickle hemoglobin (HBO) results in the substitution of valine for the glutamic acid normally present at the sixth position form the amino terminus of the beta chain of hemoglobin" (Serjeant, 1997). Valine is an amino acid that tends to form strong hydrophobic bonds. This substitution often results in polymerization or sickling or red blood cells (RBCs) when the affected individual is hypoxic, acidotic, or dehydrated or has an infection (Gribbons, Zahr, Opas, 1995). Martinelli (1991) stated that molecularly, the substitution of valine for glutamic acid provides two reactive sites when $\mathrm{HBO}$ releases oxygen. As a result, $\mathrm{HBO}$ molecules tend to bond to each other and to $\mathrm{HbA}$ at these reactive sites, forming long aggregates or tactoids. Furthermore, sickled RBCs have a propensity to adhere to the vascular endothelium, resulting in vaso-occlusion, tissue infarction, necrosis, and pain. This fact is crucial to understanding the clinical manifestations of Sickle Cell Anemia and sickle cell trait.

\section{Complications of Sickle Cell Disease}

Carvalho (1991) indicates that there is little doubt that, among health professionals, sickle cell disease remains shrouded in ignorance and misconceptions despite the many medical, psychological and socioeconomic problems associated with the disease.

Preiss (1998) indicates that there are three major sickle cell complications during 
the first years of life: dactylitis, splenic hypofunction and splenic sequestration. Dactylitis is a painful vaso-occlusion of the hands and feet. It may be accompanied by warmth, redness, swelling and fever. Dactylitis usually occurs in infants or children younger than 3 years. Treatments includes analgesics, intravenous hydration and warm compresses to the affected areas. Preiss (1998) further indicates that abnormal splenic function begins early in life with a $20 \%$ loss of function by the first birthday. By the second birthday, $50 \%$ of the splenic function is lost. This directly results in increased risk for the infection, especially among children with homozygous SS anemia. In children with Sickle Cell Anemia who are younger than 5 years old, there is a 30 to 100 fold increase in the incidence of invasive infection due to Streptococcus pneumonia.

Eckman \& Platt (1997) stipulated that there are specific problems in the management of SCD. Patients with SCD should be evaluated periodically to establish a normal baseline for the patient, identify impending problems, to update immunizations and maintain nutrition support, and to provide patients and parent education and support. A schedule table provides broad guidelines for the frequency of visits and interventions to be stressed throughout life.

Specific problems seen among SCD patients include abdominal pain. Eckman \& Platt (1997) noted that sickle pain episodes may present with pain in the abdomen and intra-abdominal pathology can precipitate pain crisis. This population has the usual problems which can present with abdominal pain, however the incidence of gallstones with cholecystitis, peptic ulcer disease, and pyelonephritis is increased. Complications such as splenic or hepatic sequestration are almost unique problems in patients with SCD. 
Allergic reactions are also common in SCD (Eckman \& Platt, 1997) and may vary in severity from mild fever, rash, pruritus, urticaria (hives), to life threatening problems or angioneurotic edema, respiratory failure, and anaphylactic with shock. Such reactions can occur after exposure to drugs, contrast material, serums, vaccines, local anesthetic agents, cosmetics, insect bites, and foods.

Anemia which is lifelong, begins in the first year of life as the fetal hemoglobin level falls. The average red cell survival is reduced from a normal of 120 days down to an average of 10 to 20 days in sickle cell anemia. This produces anemia, a high reticulocyte count, and a striking proliferation of red cell precursors in the bone marrow to compensate for the hemolysis. Other related problems related to the anemia are jaundice (elevated indirect bilirubin), changes in bone structure, and a high lactic dehydrogenase. In later childhood and early adult life, pigment gallstones are very common, related to increased catabolism of hemoglobin. These cause cholecystitis in many individuals and removal is advocated by many as soon as stones are documented. Acute anemia can be caused by an aplastic episode, sequestration, G6PD, acute chest syndrome, an allo-antibody, renal failure, or folate deficiency (Eckman \& Platt, 1997).

Back pain is also extremely common during pain episodes in patients with sickle cell syndrome. In children and young adults one must always consider renal pathology or musculoskeletal pain unrelated to the sickle syndrome. In older adults, disk disease, tumors and infection. Gynecologic disease is a consideration in sexually active female at any age (Eckman \& Platt, 1997).

Preiss (1998) stipulates that potential complications for children with SCD include 
vaso-occlusive events, splenic sequestration, bacterial septicemia from splenic hypofunction, aplastic crisis, pulmonary compromise including acute chest syndrome, renal tubular dysfunction and renal failure, priapism, aseptic necrosis, gallstones, delayed growth and development, leg ulcers, stroke and premature death.

The risk for pneumococcal meningitis is 36 times greater in children with sickle cell anemia than for black children without the disease, and 314 times greater than for white children. These children with SCD should receive scheduled immunizations, including hepatitis B series. Additionally, they should be vaccinated against pneumonia at age 2 and every 3 years to 5 years thereafter (Wong, Powars, \& Overturf, 1995). Early diagnosis and intervention are two factors that have contributed to the decline in morbidity and death rates over the last 10 years (Preiss, 1998).

Platt (1997) indicates that persons diagnosed with SCD may be at risk for depression. The day to day stresses associated with the illness may contribute to feeling of helplessness, a feeling of not being in control, and create a vulnerability to develop depressive syndrome. According to Woods (1994) patients experience problems associated with chronic disease: loss of time from school or work; unpredictable episodes of pain, fear of impending death, altered self-image, and social isolation are at greater risk for depression. The psychosocial impact of SCD has a major impact on the patients' overall well-being. Increasingly, attention is being paid to the quality of life of these and other patients with chronic disease, who are living longer as a result of advanced technology. In addition there are external realities (such as financial burdens from unemployment and the need to maintain healthcare services as adult patients) that add to 
stress and family tension.

Eckman \& Platt (1997) postulate despite many opinions to the contrary, sickle cell anemia does not predispose to or provide absolute protection from drug addiction. A small number of patients exhibit behavioral diagnostic of narcotic addiction. These patients have very frequent contact with health professionals which both compromises their health care and that of other patients with sickle cell syndromes.

Treatment of patients with drug addiction and a sickle cell syndrome poses a number of very difficult management problems. First, drug addiction compromises our ability to diagnose and treat complications in the disease. Pain episodes are less responsive to therapy in drug tolerant patients. Drug seeking behavior may mask symptoms of serious complications. Second, regular use of narcotics may make the health of sickle syndrome patients worse. For example, regular meperidine use is associated with seizures. Also withdrawal may precipitate severe acute pain episodes and other more life-threatening complications.

\section{Knowledge Level and Attitudes}

In a study conducted by Waters (1995), there was a preconceived, and misconceptived, notions about narcotic addiction and sickle cell patients many health-care professionals were reluctant to administer appropriate doses of opioids. In that same study, Waters (1995) indicates that one of the main reasons for this under-treatment is attributed to a lack of knowledge of the pharmacology of opiates, and a concern about the risk of addiction to narcotics. Lorenzi (1993) did a study on nurses' knowledge base and job satisfaction for care given, the nurse in that study verbalized feelings of frustration, 
anger and a sense of being manipulated by patients with sickle cell disease due to lack of knowledge about the disease. Such findings were also supported by Brookoff (1992) who found that people persist on mistaken belief that sickle cell can unsickled in the test tube, sickling can be reversed in the bloodstream and that one way to do that is oxygen and intravenous hydration. Not only has that treatment never shown to alleviated painful crisis, but the manual on sickle cell disease published by the Department of Health and Human Services specifically warns oxygen therapy in painful crisis can induce erythroid marrow hypoplasia and should not be used unless the patient is hypoxemic (Brookoff 1992).

Platt (1997) indicates that the complexities of sickle cell demands intricate coordination of health care services. Nurses must look beyond the illness and be advocates for patients in adjusting to the lifelong process of living with this chronic illness Hernandez, 1989). In the study conducted by Lorenzi (1993) the variable of age, educational level and unit home base did not have a statistical effect on knowledge base. The nurses in that study verbalized that, because of their increased knowledge about sickle cell disease and their subsequent attitude change towards these patients, their quality of care was even better now because it was more comprehensive and holistic.

\section{Summary}

Through the review of the literature, there has been very little research done on nurses' knowledge of Sickle Cell Disease. The major focus has been on how to manage pain when a patient is going through a crisis. Nurses' knowledge and attitudes have not been studied. Some researchers indicated that nurses need to be aware of the disease 
itself not only the illness. The care given to patients with sickle cell disease have been inadequate according the literature due to lack of knowledge of the disease process.

The review of the literature also reveals that nurses felt uneasy, frustrated and angry when not sure how to approach the different problems with patients in sickle cell crisis. Although there have been some comprehensive guidelines available to treat these patients, nurses are still reluctant to administer opioids to these patients because of fear of addiction, and lack of understanding of pharmacologic opioids and the disease process. The literature did not provide insight into the relationship between culture, age, gender, and nurses' experiences and education on how sickle cell patients are cared for. Four research questions guided further development of this study.

Research Questions:

1. To what extent are nurses knowledgeable about SCD?

2. What kind of attitude do nurses have towards patients with SCD?

3. What is the relationship between nurses ${ }^{\mathrm{C}}$ knowledge concerning sickle cell disease and their attitude toward SCD patients?

4. To what extent are nurses' attitude toward SCD patients influenced by sociodemographic factors, namely,
a. Ethnicity
b. Gender
c. Age
d. Education
e. Nursing Experience 


\section{Operational Definitions}

As used in this study, the operational definitions are as follows:

Knowledge A clear and certain perception of something, the state of knowing, of awareness, or understanding (Webster, 1996) as measured by the Knowledge Base Inventory.

$\underline{\text { Registered Nurse A graduate nurse registered and Licensed by the a State Board }}$ of Nurse Examiners or other state authority to practice nursing (Agency for Health Care Administration, 1994). Nurses who are hospital based may or may not be pursuing graduate studies.

Sickle cell disease An inherited disorder of red blood cell hemoglobin. A group of diseases characterized by the production of $\mathrm{HBO}$ resulting from the inheritance of two beta (sup s) globin genes ( $\mathrm{Hb} \mathrm{SS}$ ), a beta $\mathrm{S}$ and a beta $\mathrm{C}$ gene ( $\mathrm{Hb} \mathrm{SC}$ ), a beta $\mathrm{S}$ and a beta-Thalassemia gene ( $\mathrm{Hb} \mathrm{S}$ beta-Thalassemia), or a beta $\mathrm{S}$ gene and a gene for other abnormal hemoglobin which polymerizes with HBO (Murray, 1997).

Attitudes A manner of acting, feeling or thinking that show one's disposition, opinion (Webster, 1996) as measured by the Sickle Cell Disease Attitude Questionnaire. 


\section{CHAPTER III}

\section{Methodology}

The purpose of this study was to examine nurses' knowledge level and attitudes toward patients with Sickle Cell Disease and to determine where demographics affect nurses SCD knowledge levels and attitudes. This chapter describes the research design, sampling and setting, the data collection tools, the data collection procedure, and the method of data analysis.

\section{Design}

A descriptive-correlational approach was utilized to obtain data for this study. Self-report survey methodology was utilized including an introductory cover letter (See Appendix A). The nurse's knowledge level and attitudes were examined using the Nurses' Knowledge Base Inventory (Lorenzi, 1993). In addition, a Likert type questionnaire was designed by the principal investigator and was utilized to obtain sociodemographic data including ethnicity, gender, age, education, nursing experiences, and the type of unit worked on.

\section{Sample and Setting}

For the purpose of this study, the anticipated sample was to consist of at least 100 registered nurses. Three data collection sites were utilized for convenience sampling, including a public university and two acute care hospitals which for the purpose of this study will be identified as hospital "A" and hospital "B"., all located in South Florida. The sample of registered nurses from the public university were either BSN or MSN students. The two samples taken from the acute care hospital settings were all registered nurses 
currently employed in a hospital and working in either adult medical-surgical units, pediatrics, or as case managers, clinical care coordinators, assistant managers and managers. Subject selection was limited to nurses who read and understood English. Variables

The study sought to understand and evaluate the relationship of the following variables:

Independent Variables: Knowledge regarding Sickle Cell Disease and demographic variables of age, years of clinical nursing experience, gender, education, and ethnicity.

Dependent Variable: Attitudes regarding Sickle Cell Disease.

\section{Instruments}

The instruments chosen for this study included the Nurses' Knowledge Base Inventory regarding patients with sickle cell disease (Lorenzi, 1993), a Sickle Cell Disease Attitude Questionnaire, which was designed by the investigator, and a 9-item demographic questionnaire.

The Nurses' Knowledge Base Inventory (Lorenzi, 1993) is a twenty-item pencil and paper self-report survey which includes ten multiple-choice items and ten true or false items. (See Appendix B). The instrument was scored based upon a percentage basis of correct answers. Scores range from 0 to 20 , with the higher score representing a higher level of knowledge.

The Sickle Cell Disease Attitude Questionnaire is purported to measure the nurses? attitudes towards sickle cell patients and aspects of providing care for them (See Appendix C). The questionnaire consists of 12 statements which the subjects are asked to indicate 
their level of agreement, ranked on a 5-point Likert-type scale. The responses range from 1 (strongly agree) to 5 (strongly disagree). Eleven of the items are negatively worded and were scored as indicated by the study participants. One item is positively worded and was scored inversely. Scores range from 12 to 60 points, with a higher score representing a more positive attitude towards the sickle cell patient. The Sickle Cell Disease Attitude Questionnaire was evaluated for internal reliability with a Spearman's rho coefficient of 0.77 , suggesting a fairly high internal consistency.

The 9-item researcher-created demographic questionnaire (See Appendix D) contains eight multiple choice questions including years of clinical nursing experience, gender, highest level of education, current level of practice, type of unit worked on, ethnicity, marital status and religious preference. The questionnaire also contains one open-ended question for age.

Content validity and construct validity was also established for the Nurses' Knowledge Base Inventory and the Demographic Questionnaire by the researcher prior to the use of the instrument (Spearman Brown reliability coefficient $=0.77$ ). In addition, the data collection instruments were reviewed by four different expert medical professionals on Sickle Cell Disease to establish face and content validity.

\section{Data Collection and Protection of Human Subjects}

The data collection and recruitment of subjects was initiated after receiving permission from the Florida International University research committee and approval of the University and hospitals' internal review boards. Subjects were recruited by the principal investigator in the pediatric unit, medical-surgical, orthopedics, telemetry, 
intensive and coronary care units of the hospital and at the University chosen. The students and nurses were advised in the cover letter that completion of the questionnaire implied informed consent to participate in the study. Secure drop off boxes were located on each unit and were emptied only by the principal investigator. After data analysis, the questionnaires were stored in a secure area in the principal investigator's office at home in a locked filing cabinet where they will remain for 3 years, after which time they will be appropriately destroyed. Written and verbal instructions and a description of measures to ensure confidentiality and anonymity were provided within the cover letter. Subjects were assured of confidentiality and anonymity, and were told that they could have withdrawn from the study at any time without any harm or any unexpected surprises. Each subject was instructed to place their completed survey in the envelope provided, seal it, and drop it in the selected drop-off box located on each unit.

\section{Method of Data Analysis}

The Statistical Package for Social Sciences (SPSS, 1997) version 7.0 for windows was used to analyze data. Descriptive statistical techniques including frequency distributions, measures of central tendency and variance were used to measure the extent acute care nurses and nurses at the University were knowledgeable about SCD as well as their attitudes toward patients with sickle cell disease. The Kolmogorov Smirnov Goodness of Fit Test was performed to assess whether these knowledge and attitude scores were normally distributed, and subsequently, the appropriate inferential statistical techniques were used to analyze the relationship between disease knowledge and attitudes (Spearman's rho Correlation Test), as well as selected demographic variables, (One-Way 
Analysis of Variance (ANOVA), $t$ test for independent samples). 


\section{CHAPTER IV}

\section{Presentation of Findings}

A total of 109 completed questionnaires were returned, depicting a $55 \%$ response rate. The data were analyzed utilizing the SPSS (1997) statistical program. The Kolmogorov Smirnov Goodness of Fit Test was performed and revealed nonparametric sample distributions for both the knowledge base inventory $(p=017)$ and the sickle cell disease attitude questionnaire $(\mathrm{p}=.488)$ The independent samples $t$-test was performed to compare the equality of means at the $95 \%$ confidence interval. The results revealed $(t=0.930, d f=76, p=0.356)$. This chapter presents the research findings.

\section{Sample Characteristics}

As depicted in Table 1, the sample comprised predominantly of females $(92.7 \%)$, between 26 and 35 years old (38.5\%), and were married (60.6\%). Male nurses only composed $6.4 \%$ of the sample. Ethnicity indicated was nearly even for blacks (33.9\%) and whites (32.1\%). Asians (22.0\%) and Hispanic/Latin nurses (11.9\%) completed the sample. Ten nurses indicated they were divorced or separated $(9.2 \%)$, while one nurse did not provide a response $(0.9 \%)$. A large percentage of nurses indicated that they were Catholic $(38.5 \%)$. The majority of nurses, however, selected a religious preference of "other" (43.1\%).

Table 2 depicts the characteristics of the sample according to education and professional experience. Years of clinical experience indicated by the nurses were most often 11 to 19 years $(25.7 \%)$, more than 20 years $(23.9 \%)$ and six to 10 years $(22.0 \%)$. Nineteen of the nurses $(17.4 \%)$ indicated that they had between one and five years of 
experience, and eleven indicated that they had less than one year (10.1\%). One nurse $(0.9 \%)$ did not provide a response for years of clinical experience. The highest level of education indicated by the nurses was a BSN degree (56.9\%). Educational levels of AND $(16.5 \%)$ and Diploma (15.7\%) were also reported. Seven study participants were educated at the MSN level (6.5\%), and four nurses held a Ph.D. (3.7\%). One nurse did not provide a response to the highest level of education $(0.9 \%)$. The nurses were most often employed as staff nurses $(72.5 \%)$. Twenty-one nurses selected "other" as the response for current level of practice (19.2\%). Two nurses indicated that they were nurse managers $(1.8 \%)$. Many of the nurses indicated that they worked on either a medicalsurgical unit $(23.9 \%)$ or a pediatric unit $(20.2 \%)$. Telemetry $(11.9 \%)$ and Intensive care (11.9\%) were also indicated as areas worked. Nineteen nurses $(17.4 \%)$ selected "other" to describe their work unit.

The three sites used for data collection were comparable in pesonal demographic composition with respect to age, ethnicity, marital status, religious preference. With respect to gender, the sample from the University was all female, and the sample from hospital site A contained only two males. The remainder of the 5 males were from hospital site B. Education and professional experience among the three sites was comparable with respect to years of clinical experience. The highest levels of education reported among the sample were noted at the university. The nurses from the University were noted to select "other" most frequently to describe both their current level of practice and work unit, variables which were evenly selected at each of the two hospital sites. 
Table 1.

Frequency Distribution of the Sample by Personal Attributes $(n=109)$

\begin{tabular}{lcr}
\hline Variable & Frequency & Percent \\
\hline Age Group & & \\
& & $8.3 \%$ \\
25 years or younger & 09 & $38.5 \%$ \\
$26-35$ years of age & 42 & $32.1 \%$ \\
$36-45$ years of age & 35 & $11.9 \%$ \\
$46-55$ years of age & 13 & $3.7 \%$ \\
56 years or older & 04 & $5.5 \%$ \\
No response & 06 & \\
\hline
\end{tabular}

Gender

Female

$92.7 \%$

Male

07

$6.4 \%$

No response

01

$0.9 \%$

Ethnicity

Black

White

Asian/Pacific Islander

Hispanic/Latino

37

35

24

13
$33.9 \%$

$32.1 \%$

$22.0 \%$

$11.9 \%$

\section{Marital Status}

Married

Single

Divorced/Separated

Living with primary partner

No Response
66

28

10

04

01
$60.6 \%$

$25.7 \%$

$9.2 \%$

$3.6 \%$

$0.9 \%$

\section{Religious Preference}

Catholic

Protestant

Jewish

No Response 
Table 2.

Frequency Distribution of the Sample by Education and Professional Experience $(n=109)$

Variable

Frequency

Percent

Highest level of education

$\begin{array}{llr}\text { AND } & 18 & 16.5 \% \\ \text { Diploma } & 17 & 15.7 \% \\ \text { BSN } & 62 & 56.9 \% \\ \text { MSN } & 07 & 6.5 \% \\ \text { PhD } & 04 & 3.7 \% \\ \text { No response } & 01 & 0.9 \%\end{array}$

Years of clinical experience

Less than 1 year 11

$1-5$ years 19

6-10 years 24

$11-19$ years 28

More than 20 years 26

No response 01

$10.1 \%$

$17.4 \%$

$22.0 \%$

$25.7 \%$

$23.9 \%$

$0.9 \%$

Current level of practice

Staff nurse

Patient care coordinator

Assistant nurse manager

03

Nurse manager

02

Other

21

$72.5 \%$

$3.7 \%$

$2.8 \%$

$1.8 \%$

$19.2 \%$

Work unit

$\begin{array}{lrr}\text { Medical/Surgical } & 26 & 23.9 \% \\ \text { Pediatrics } & 22 & 20.2 \% \\ \text { Telemetry } & 13 & 11.9 \% \\ \text { Intensive care } & 13 & 11.9 \% \\ \text { Critical care } & 09 & 8.3 \% \\ \text { More than one unit } & 05 & 4.6 \% \\ \text { Emergency room } & 01 & 0.9 \% \\ \text { Other } & 19 & 17.4 \% \\ \text { No response } & 01 & 0.9 \%\end{array}$




\section{Findings Relating to the Research Questions}

\section{To what extent are nurses knowledgeable about SCD?}

Table 3 depicts the knowledge base scores reported in the frequency of correct responses and corresponding percentage of the total group for each study site and overall sample relating to individual test items.

The possible SCD knowledge (SCDK) scores ranged from 0 to 20 points with a higher score representing a higher level of knowledge. In this study, the scores for the sample ranged from 7 to 18 points, the mean SCDK score being 13.11 points $(\mathrm{sd}=1.97)$ scored anywhere. When examined by study site, Hospital A nurses ranged 9 to 16 points, yielding a mean score of $12.68(\mathrm{sd}=1.59)$. The scores among Hospital B nurses ranged from 7 to 18 points, with a mean score of $13.45(\mathrm{sd}=2.54)$. The nurses from the university scored from 9 to 17 , yielding a mean score of $13.43(\mathrm{sd}=1.79)$.

The accuracy of responses to individual questions on the Knowledge Base Inventory varied. Several of the individual questions were answered correctly with 100 percent accuracy. One question, number 8 , regarding oxygen delivery to the sickle cell patient only for a p02 of $75 \mathrm{mmHg}$ or less, was answered incorrectly by all of the study participants.

A significant percentage of the nurses demonstrated a high level of knowledge when questioned regarding SCD classification as a genetic disorder $(97.8 \%)$, however they poorly comprehended that the classic form was HbSS (38.5\%). Nearly all of the nurses $(93.4 \%)$ knew that vaso-occlusion was the most common SCD event and that any organ could have vessel occlusion $(96 \%)$. While a significant number of nurses knew that 
monitoring of $I \& O$ was important $(80.2 \%)$ and that the urine color and consistency should be observed $(87.8 \%)$, they poorly comprehended that a minimum daily intake of 3 liters of fluid was needed (38.6\%) or that the best choices of fluids for the SCD patient were pop, juices and broth (25.9\%). The nurses also knew that the urine was monitored for hyposthenuria and uremia ( $80.2 \%)$, and that SCD patients could easily develop hyponatremia $(88.3 \%)$. Also related to the pathophysiology of $\mathrm{SCD}$, slightly more than one-third (35.6\%) of the nurses correctly identified that the sickle cell RBC lifespan was from 10-15 days. The fact that gallstones were common in SCD was known by $69.1 \%$ ) of the sample.

The fact that priapism is painful was understood by $91.5 \%$ of the sample, and $96.4 \%$ knew that new areas of pain could develop in a crisis. When asked about conservative interventions for pain management, $86.8 \%$ of the nurses selected a combination of approaches including bedrest, heat, relaxation, and distraction. The nurses demonstrated a moderate understanding of coping mechanisms utilized by the SCD patient $(68.4 \%)$, however $91.3 \%$ indicated that they knew emotional factors could precipitate a crisis.

The nurses demonstrated a poor understanding that $30 \%$ of painful crises were caused by infection (14.3\%) or that Hemophilus influenza was usually not the causative microorganism for pneumonia in SCD (41.0\%). 
Table 3.

Knowledge Base Inventory Item Correct Response Scores, by Study Site

\begin{tabular}{|c|c|c|c|c|c|c|c|c|}
\hline \multirow[t]{2}{*}{ Items } & \multicolumn{2}{|c|}{$\begin{array}{l}\text { Hospital A } \\
(\mathrm{n}=48)\end{array}$} & \multicolumn{2}{|c|}{$\begin{array}{l}\text { University } \\
\qquad(\mathrm{n}=30)\end{array}$} & \multicolumn{2}{|c|}{$\begin{array}{l}\text { Hospital B } \\
\qquad(\mathrm{n}=31)\end{array}$} & \multicolumn{2}{|c|}{$\begin{array}{l}\text { Overall } \\
\text { Sample } \\
(\mathrm{n}=109)\end{array}$} \\
\hline & $f$ & $\%$ & $f$ & $\%$ & $f$ & $\%$ & $\mathrm{f}$ & $\%$ \\
\hline $\begin{array}{l}\text { 1) Minimum daily intake } \\
\text { of fluids: } 3 L / \text { day }\end{array}$ & 21 & 43.8 & 9 & 30.0 & 13 & 41.9 & 43 & 38.6 \\
\hline $\begin{array}{l}\text { 2) Best choice of fluids: } \\
\text { pop, juices, broth }\end{array}$ & 9 & 18.8 & 9 & 29.0 & 9 & 29.0 & 27 & 25.9 \\
\hline $\begin{array}{l}\text { 3) Monitor vital signs to } \\
\text { detect: all of the above }\end{array}$ & 35 & 72.9 & 26 & 86.7 & 23 & 74.2 & 28 & 77.9 \\
\hline $\begin{array}{l}\text { 4) Classic sickle-cell } \\
\text { anemia is: HbSS }\end{array}$ & 16 & 33.3 & 15 & 50.0 & 10 & 32.3 & 41 & 38.5 \\
\hline $\begin{array}{l}\text { 5) Sickle-cell anemia is } \\
\text { a: genetic disorder }\end{array}$ & 48 & 100.0 & 30 & 100.0 & 29 & 93.5 & 116 & 97.8 \\
\hline $\begin{array}{l}\text { 6) Sickle cell RBC } \\
\text { lifespan: } 10-15 \text { days }\end{array}$ & 12 & 25.0 & 11 & 36.7 & 14 & 45.2 & 37 & 35.6 \\
\hline $\begin{array}{l}\text { 7) } 30 \% \text { of painful crisis } \\
\text { is caused by: infection }\end{array}$ & 8 & 16.7 & 3 & 10.0 & 5 & 16.1 & 16 & 14.3 \\
\hline $\begin{array}{l}\text { 8) Oxygen is ordered for: } \\
\text { pO2 } 75 \mathrm{mmHg} \text { or less }\end{array}$ & 0 & 0.0 & 0 & 0.0 & 0 & 0.0 & 0 & 0.0 \\
\hline $\begin{array}{l}\text { 9) Conservative pain } \\
\text { therapy constitutes: } \\
\text { all the above (bedrest, } \\
\text { heat, relaxation and } \\
\text { distraction }\end{array}$ & 37 & 77.1 & 25 & 83.3 & 31 & 100.0 & 93 & 86.8 \\
\hline $\begin{array}{l}\text { 10) Coping mechanisms } \\
\text { used in SCD: all the } \\
\text { above (repression, } \\
\text { regression, displace- } \\
\text { ment, projection, } \\
\text { sublimation }\end{array}$ & 26 & 54.2 & 23 & 76.7 & 23 & 74.2 & 72 & 68.4 \\
\hline
\end{tabular}




\begin{tabular}{|c|c|c|c|c|c|c|c|c|}
\hline \multirow[t]{2}{*}{ Items } & \multicolumn{2}{|c|}{$\begin{array}{l}\text { Hospital A } \\
(n=48)\end{array}$} & \multicolumn{2}{|c|}{$\begin{array}{l}\text { University } \\
\qquad(\mathrm{n}=30)\end{array}$} & \multicolumn{2}{|c|}{$\begin{array}{l}\text { Hospital B } \\
\quad(\mathrm{n}=31)\end{array}$} & \multicolumn{2}{|c|}{$\begin{array}{l}\text { Overall } \\
\text { Sample } \\
(\mathrm{n}=109)\end{array}$} \\
\hline & $\mathrm{f}$ & $\%$ & $\mathrm{f}$ & $\%$ & $\mathfrak{f}$ & $\%$ & & \\
\hline $\begin{array}{l}\text { 11) I\&O monitoring is for } \\
\text { hyposthenuria and } \\
\text { uremia }\end{array}$ & 26 & 54.2 & 23 & 76.7 & 23 & 77.4 & 88 & 80.2 \\
\hline $\begin{array}{l}\text { 12) Vaso-occlusion is the } \\
\text { most common SCD } \\
\text { event }\end{array}$ & 48 & 100.0 & 26 & 86.7 & 29 & 93.5 & 103 & 93.4 \\
\hline $\begin{array}{l}\text { 13) } \mathrm{H} \text {. Influenza usually } \\
\text { does not cause } \\
\text { pneumonia in SCD }\end{array}$ & 12 & 25.0 & 13 & 43.3 & 17 & 54.8 & 42 & 41.0 \\
\hline $\begin{array}{l}\text { 14) SCD urine color and } \\
\text { consistency must be } \\
\text { recorded }\end{array}$ & 40 & 83.3 & 26 & 86.7 & 29 & 93.5 & 95 & 87.8 \\
\hline $\begin{array}{l}\text { 15) Emotional factors can } \\
\text { precipitate a crisis }\end{array}$ & 48 & 100.0 & 3 & 10.0 & 5 & 16.1 & 101 & 91.3 \\
\hline $\begin{array}{l}\text { 16) Any organ can have } \\
\text { vessel occlusion }\end{array}$ & 47 & 97.9 & 29 & 96.7 & 29 & 93.5 & 105 & 96.0 \\
\hline 17) Priapism is painful & 42 & 87.5 & 30 & 100.0 & 27 & 87.1 & 99 & 91.5 \\
\hline $\begin{array}{l}\text { 18) SCD patients develop } \\
\text { hyponatremia }\end{array}$ & 42 & 87.5 & 29 & 96.7 & 25 & 80.6 & 96 & 88.3 \\
\hline $\begin{array}{l}\text { 19) New areas of pain can } \\
\text { develop in a crisis }\end{array}$ & 46 & 95.8 & 30 & 100.0 & 29 & 93.5 & 115 & 96.4 \\
\hline $\begin{array}{l}\text { 20) Gallstones are } \\
\text { common in SCD }\end{array}$ & 32 & 66.7 & 19 & 63.3 & 24 & 77.4 & 75 & 69.1 \\
\hline Total Correct & $\begin{array}{l}609 \\
\mathrm{~m}=1 \\
(\mathrm{sd}=\end{array}$ & $\begin{array}{l}63.4 \\
2.68 \\
1.59)\end{array}$ & $\begin{array}{r}344 \\
\mathrm{~m}= \\
(\mathrm{sd}=\end{array}$ & $\begin{array}{r}62.1 \\
13.43 \\
1.79)\end{array}$ & $\begin{array}{l}417 \\
\mathrm{~m}=1 \\
(\mathrm{sd}=\end{array}$ & $\begin{array}{l}67.2 \\
3.45 \\
2.54)\end{array}$ & $\begin{array}{l}1370 \\
\mathrm{~m}=1 \\
(\mathrm{sd}=\end{array}$ & $\begin{array}{l}64.3 \\
13.11 \\
1.97)\end{array}$ \\
\hline
\end{tabular}




\section{What kind of attitude do nurses have towards patients with SCD?}

Table 4 depicts the Sickle Cell Disease Attitude scores reported by the means and standard deviations of the responses for each study site and overall sample relating to each statement.

The sickle cell disease attitude questionnaires were evaluated to determine the level of agreement with each statement, with numerical values assigned to the level of agreement according to the ranking on a five point scale from $1-5$, with $1=$ "strongly agree" to $5=$ "strongly disagree". Possible scores ranges from 12 to 60 , with a higher score representing a more positive attitude towards caring for the sickle cell patient. The minimum score achieved among the sample was 32 and the maximum score was 60.0 . The mean score was $46.4(\mathrm{sd}=6.7)$. When examined by study site, the scores among nurses from hospital A ranged from 32 to 60 , with a mean score of $45.2(\mathrm{sd}=6.9)$. The scores among nurses from hospital B ranged from 34 to 55 , with a mean score of 43.8 $(s d=5.6)$. The nurses from the university scored from 35 to 60 , with a mean score of 51.2 $(\mathrm{sd}=5.7)$.

As depicted in Table 5, when examined by ethnicity, the scores among the overall sample ranged from 32 to 60 , with a mean score of $46.4(\mathrm{sd}=6.9)$. The scores among White nurses ranged from 34 to 60 , with a mean score of $46.7(\mathrm{sd}=7.3)$. The Blacks scores ranged form 32 to 58 , with a mean score of $44.8(\mathrm{sd}=6.4)$. Hispanics scores ranged from 38 to 60 , with a mean score of $50.3(\mathrm{sd}=6.9)$, and Asian/Pacific Islanders scores ranged from 37 to 60 , with a mean score of $46.4(\mathrm{sd}=6.2)$. 
Table 4.

Sickle Cell Disease Attitude Scores, by Study Site

\begin{tabular}{|c|c|c|c|c|c|c|c|c|}
\hline \multirow[t]{2}{*}{ Statement } & \multicolumn{2}{|c|}{$\begin{array}{l}\text { Hospital A } \\
\qquad(n=47)\end{array}$} & \multicolumn{2}{|c|}{$\begin{array}{l}\text { University } \\
\qquad(\mathrm{n}=30)\end{array}$} & \multicolumn{2}{|c|}{$\begin{array}{l}\text { Hospital B } \\
\qquad(n=31)\end{array}$} & \multicolumn{2}{|c|}{$\begin{array}{l}\text { Overall } \\
\text { Sample } \\
(n=108)\end{array}$} \\
\hline & $\mathrm{m}$ & $\mathrm{sd}$ & $\mathrm{m}$ & $\mathrm{sd}$ & $\mathrm{m}$ & sd & $\mathrm{m}$ & $\mathrm{sd}$ \\
\hline $\begin{array}{l}\text { 1) Giving nursing care to } \\
\text { patients with sickle cell } \\
\text { disease is frustrating. }\end{array}$ & 3.0 & 1.4 & 3.8 & 1.1 & 2.8 & 1.2 & 3.2 & 1.2 \\
\hline $\begin{array}{l}\text { 2) When giving nursing care I } \\
\text { would be upset when a sickle } \\
\text { cell patient presses the call bell } \\
\text { repeatedly. }\end{array}$ & 3.4 & 1.2 & 3.8 & 1.3 & 3.4 & 0.9 & 3.5 & 1.1 \\
\hline $\begin{array}{l}\text { 3) I feel that sickle cell } \\
\text { patients aren't really in pain } \\
\text { when they say so. }\end{array}$ & 4.0 & 0.8 & 4.7 & 0.6 & 3.7 & 1.1 & 4.1 & 0.8 \\
\hline $\begin{array}{l}\text { 4) I would purposely withhold } \\
\text { pain medication because I } \\
\text { believe sickle cell patients } \\
\text { might become addicted to the } \\
\text { pain medication. }\end{array}$ & 4.6 & 0.5 & 4.7 & 0.6 & 4.6 & 0.6 & 4.5 & 0.6 \\
\hline $\begin{array}{l}\text { 5) I feel that sickle cell } \\
\text { patients should receive a } \\
\text { placebo when they complain } \\
\text { of pain. }\end{array}$ & 4.1 & 1.0 & 4.8 & 0.6 & 4.1 & 0.8 & 4.3 & 0.8 \\
\hline $\begin{array}{l}\text { 6) I treat all sickle cell patients } \\
\text { like any other patient. }\end{array}$ & 2.4 & 1.3 & 2.7 & 1.5 & 2.1 & 1.1 & 2.4 & 1.3 \\
\hline
\end{tabular}




\begin{tabular}{|c|c|c|c|c|c|c|c|c|}
\hline \multirow[t]{2}{*}{ Statement } & \multicolumn{2}{|c|}{$\begin{array}{l}\text { Hospital A } \\
(n=47)\end{array}$} & \multicolumn{2}{|c|}{$\begin{array}{l}\text { University } \\
\qquad(n=30)\end{array}$} & \multicolumn{2}{|c|}{$\begin{array}{l}\text { Hospital B } \\
(n=31)\end{array}$} & \multicolumn{2}{|c|}{$\begin{array}{r}\text { Overall } \\
\text { Sample } \\
(\mathrm{n}=108)\end{array}$} \\
\hline & $\mathrm{m}$ & $\mathrm{sd}$ & $\mathrm{m}$ & sd & $\mathrm{m}$ & sd & $\mathrm{m}$ & sd \\
\hline $\begin{array}{l}\text { 7) It is hard to form a close } \\
\text { relationship with sickle cell } \\
\text { patients. }\end{array}$ & 3.8 & 1.1 & 4.5 & 0.7 & 4.0 & 0.9 & 4.1 & 0.9 \\
\hline $\begin{array}{l}\text { 8) I hope that I am not } \\
\text { assigned to care for a sickle } \\
\text { cell patient. }\end{array}$ & 4.3 & 0.8 & 4.6 & 0.7 & 4.0 & 1.0 & 4.3 & 0.8 \\
\hline $\begin{array}{l}\text { 9) I think sickle cell patients } \\
\text { are admitted in the hospital too } \\
\text { frequently. }\end{array}$ & 3.0 & 1.4 & 4.2 & 0.8 & 3.5 & 1.3 & 3.6 & 1.2 \\
\hline $\begin{array}{l}\text { 10) I seldom empathize with } \\
\text { sickle cell patients and their } \\
\text { families. }\end{array}$ & 4.2 & 0.8 & 4.3 & 1.1 & 3.7 & 1.3 & 4.1 & 1.1 \\
\hline $\begin{array}{l}\text { 11) I am afraid to give nursing } \\
\text { care to sickle cell patients } \\
\text { because I think they are angry } \\
\text { and violent patients. }\end{array}$ & 4.5 & 0.8 & 4.7 & 0.5 & 4.5 & 0.6 & 4.6 & 0.7 \\
\hline $\begin{array}{l}\text { 12) The amount of time it } \\
\text { takes to give nursing care and } \\
\text { pain medication to the patients } \\
\text { with sickle cell disease would } \\
\text { frustrate me. }\end{array}$ & 3.8 & 1.1 & 4.4 & 0.6 & 3.6 & 1.2 & 3.9 & 0.9 \\
\hline Total Scores & 45.2 & 6.9 & 51.2 & 5.7 & 43.8 & 5.6 & 46.4 & 6.9 \\
\hline
\end{tabular}


What is the relationship between nurses' knowledge concerning SCD and their attitude towards SCD patients?

Spearman's Rho Correlation Coefficient was performed comparing the attitude and knowledge scores among the three sites. For hospital A, the correlation coefficient between knowledge and attitude scores was $r=.05$, for Hospital $B$ the score was $r=.27$, and for the university group, the correlation was $r=.10$, at probability levels ranging from $p=.272$ to $p=.724$. These findings were not significant.

To what extent are nurses' attitude toward SCD patients influenced by sociodemographic factors, namely, ethnicity, gender, age, education, and nursing experience?

A one-way analysis of variance (ANOVA) analysis was performed among the sample to evaluate the differences in attitude scores among the four ethnic groups: 1) Whites, 2) Blacks, 3) Hispanics, and 4) Asian/Pacific Islanders. As depicted in Tables 5 and 6, the ethnic groups did not differ in attitude scores, however, a strong trend was revealed $(p=0.09)$ suggesting ethnic differences in attitudes toward $S C D$. The group with the highest mean score (indicating the most favorable attitudes in caring for the sickle cell patient) was seen among the Hispanics $(m=50.31, s d=6.87)$. The Whites scored nearly identically with the Asian/Pacific Islanders $(\mathrm{m}=46.71, \mathrm{sd}=7.28$ and $\mathrm{m}=46.35, \mathrm{sd}=6.24$, respectively). Blacks yielded the lowest attitude scores $(\mathrm{m}=44.84, \mathrm{sd}=6.44)$. 
Table 5 .

Descriptive Analysis of Attitude Scores, by Ethnicity $(n=108)$

\begin{tabular}{|c|c|c|c|c|c|c|c|}
\hline \multirow[b]{2}{*}{ Ethnic Group } & \multirow[b]{2}{*}{ n } & \multirow[b]{2}{*}{$\min$} & \multirow[b]{2}{*}{$\max$} & \multirow[b]{2}{*}{ mean } & \multirow[b]{2}{*}{ sd } & \multicolumn{2}{|c|}{$\begin{array}{l}95 \% \text { confidence } \\
\text { Interval for Mean }\end{array}$} \\
\hline & & & & & & $\begin{array}{l}\text { Lower } \\
\text { Bound }\end{array}$ & $\begin{array}{l}\text { Upper } \\
\text { Bound }\end{array}$ \\
\hline White & 35 & 34 & 60 & 46.71 & 7.28 & 44.21 & 49.22 \\
\hline Black & 37 & 32 & 58 & 44.84 & 6.44 & 42.69 & 46.99 \\
\hline Hispanic/Latino & 13 & 38 & 60 & 50.31 & 6.87 & 46.15 & 54.46 \\
\hline $\begin{array}{l}\text { Asian/Pacific } \\
\text { Islander }\end{array}$ & 23 & 37 & 60 & 46.43 & 6.24 & 43.65 & 49.05 \\
\hline Overall Sample & 108 & 32 & 60 & 46.43 & 6.85 & 45.12 & 47.73 \\
\hline
\end{tabular}

Table 6.

One-Way ANOVA Analysis of Attitude Scores, by Ethnicity $(n=107)$

\begin{tabular}{lccccc}
\hline Attitude & $\begin{array}{c}\text { Sum of } \\
\text { Squares }\end{array}$ & df & $\begin{array}{c}\text { Mean } \\
\text { Square }\end{array}$ & F & Sig. \\
\hline Between Groups & 292.251 & 3 & 97.417 & 2.145 & 0.099 \\
Within Groups & 4722.157 & 104 & 45.405 & \\
\hline Total & 5014.407 & 107 & & \\
\hline
\end{tabular}

Confidence Level: $p=.05$ 
Spearman's Rho Correlation Coefficients were performed comparing the attitude scores with the demographic factors of gender and age. The findings for these demographic factors did not reach the confidence level $(p \leq .05)$ and hence were not significant.

Concerning education and nursing experience, the research findings are depicted in Table 7. Spearman's Rho Correlation Coefficients were performed comparing the attitude scores with the demographic variables of level of education and clinical experience. One statistically significant correlation was revealed. As the level of formal academic education increased, the attitude level also increased $(r=.23, p=.015)$.

Experience was not found to significantly impact knowledge or attitude, and education did not significantly impact knowledge of SCD. While there was a negative correlation between education and knowledge, the finding was not significant $(r=-.047, p=.87)$ Table 7

Relationships Among Knowledge, Attitude, Education and Experience $(\mathrm{n}=108)$

Variable

Attitude

Knowledge

$$
-.047
$$

$\mathrm{p}=.875$
Experience

\footnotetext{
* significant
} 


\section{Summary}

The statistical analysis of the sample responses revealed no statistically significant differences among the knowledge or attitudes of nurses caring for sickle cell patients for the total sample based upon ethnicity. Knowledge of SCD was not shown to significantly correlate with attitudes related to caring for the SCD patient. While ethnicity did not statistically impact knowledge or attitudes, the Blacks which comprise the ethnic group with the highest incidence of SCD, scored the lowest on the attitude scale. Formal academic education was noted to have a statistically significant impact $(p=0.015)$ upon attitudes, but not knowledge. 


\section{CHAPTER V}

\section{Discussion of Findings, Implications, Limitations, and Recommendations}

This chapter presents a discussion of the study findings and conclusion drawn. Implications of the findings for nursing practice and education are detailed. Study limitations and corresponding recommendations are also presented.

The purpose of this study was to examine nurses' knowledge level of sickle cell disease and their attitudes regarding patients with sickle cell disease (SCD). The overall goal of the study was to add to the existing knowledge about SCD and attitudes affecting care of the SCD patient. It has been pointed out that nurses experience frustration, anger and uneasiness when they are required to care for SCD patients, particularly those in SCD crisis. Inadequate pharmacological therapy, specifically pain management, has been documented with nurses often reported as having biased or unsubstantiated beliefs that the use of narcotic medications in the SCD patient is inappropriate and will lead to dependency (Carvalho, 1991; Waters, 1995). Nurses have even expressed feelings of manipulation when drug abuse is suspected in the SCD patient (Eckman \& Platt, 1997; Lorenzi, 1993).

The findings indicate that the nurses surveyed in this study have a fair knowledge level $(\mathrm{m}=13.11, \mathrm{sd}=1.97)$ regarding $\mathrm{SCD}$, correctly answering $66.6 \%$ of the survey questions. Incorrect responses were noted most often among questions relating to pain management, appropriate assessment and treatment provision, identification of complications, and other holistic factors including psychosocial factors. These findings are consistent with the previous studies conducted by Platt (1997) with regard to gallbladder 
disease in the SCD patient, and Preiss (1998) regarding priapism. In this study, 69.1\% of the nurses demonstrated understanding of the correlation between SCD and the increased incidence of gallstones. With respect to priapism, $91.5 \%$ of the nurses recognized that the condition was painful. Knowledge of this fact was noted to be $100 \%$ accurate among the male nurses surveyed, however, this may represent gender-specific knowledge and not nursing knowledge specifically.

Of the study respondents, $91.3 \%$ correctly identified that emotional crises or stress affected the SCD patient negatively. This is consistent with previous findings and observances reported by Platt (1997) and Woods (1994). Only 68.4\% of the nurses in this study demonstrated understanding of the coping mechanisms utilized by SCD patients and may represent not only a knowledge deficit, but a deficit in the provision of adequate counseling and referral of SCD patients for support in dealing with their disease.

The findings among this sample of nurses are consistent with those of Lorenzi (1993) who also reported no difference in knowledge related to demographic variables of age, and working assignment. Inconsistent with the findings of Lorenzi (1993) was the statistically significant inverse correlation seem among the demographic variable of formal educational level and attitudes regarding SCD. In this sample popluation, as the level of formal education increased, the attitude score decreased. Nurses in Lorenzi's study (1993) demonstrated an increased level in the quality of care which directly correlated with the level of education.

While the overall knowledge and attitudes of the nurses in this study were moderately high, the need has been evidenced for disease-specific education regarding the 
holistic care of the SCD patient.

Several factors may have impacted the comprehensiveness and reliability of the study findings, namely, the demographic composition of the sample, particularly with respect to gender, ethnicity, and sample size, and the methods used for data collection.

Encroachment of participants' care-giving time was also found to be a sensitive issue in the inpatient hospital care areas and may have resulted in diminished participation by nurses in busier work areas. This was particularly noted in the emergency department setting, where only one respondent was noted. Minimal writing was required by the participants on the demographic form, and completion of the questionnaires.

Other limitations included small sample size $(n=109)$, gender represented by predominantly females, and the geographical location of three sites, all within the same county. Both hospitals were also privately owned and funded facilities. Hispanic nurses were also minimally represented in this study (11.9\%), a finding which is inconsistent with the demographic composition of the county in which the study took place, where Hispanics account for slightly over half of the population. The findings of this study may therefore not be representative of attitudes and knowledge of all nurses caring for SCD patients.

Implications for Nursing

The findings of this study contribute to the available literature regarding nurses' knowledge and attitudes towards patients with $\mathrm{SCD}$. If nurses are misinformed or biased regarding interventions and management of the SCD patient, then to what degree, if at all, do their behaviors affect patient care outcomes? An increased awareness among nurses 
that their care delivery choices may affect the patient's outcome is needed. If nurses can better understand the disease pathophysiology and appropriate management of the SCD patient, and discard unfounded concerns of addiction, more holistic and effective care delivery can be facilitated.

The findings from this study indicate that a knowledge deficit regarding SCD exists among this sample of South Florida nurses. Surprisingly, the poorest attitudes regarding the care of the SCD patient are seen among the Black nurses. There are no significant correlations between knowledge level of SCD and the attitudes reported by nurses. Formal education has an inverse effect upon attitudes. As nurses in the sample became more educated their attitude towards the SCD patient became poorer. The need for education among nurses caring for SCD patients has been evidenced, however, formal education appears not to be the solution. Further research must be conducted to better understand the complexities involved in caring for the SCD patient.

\section{Limitations and Recommendations}

Attention is directed to the limitations of the study as described below.

1) The study was conducted utilizing a small non-random sample. The study should be replicated with a larger sample including one with more male nurse representation, utilizing random sampling techniques and in geographically different locations. The study should also be replicated in a public hospital setting, serving a mostly indigent population, and a private hospital setting, where the care recipients are mostly insured, to evaluate differences among nurses caring for sickle cell patients. The study should also be replicated with a greater representation or concentration in areas with high 
percentages of contact with sickle cell patients, especially the emergency department.

2) Specific aspects relating to the nurses studied were noted to be limitations of the study, including assessment of education level to formal education only. Further study should include the assessment of credentials (CCRN, ACLS, CEN, ENPC, LPN) to determine if specialization impacts attitudes or knowledge. In addition, the study should be replicated in facilities which are associated with a teaching university and in those which are not to evaluate for differences.

3) Limitation was noted with the data collection instruments. The demographic data collection form elicited minimal information from which inferences could be drawn regarding significant factors affecting the knowledge or attitudes toward SCD patients beyond basic education and years of experience. It was also noted that there was no provision in the demographic form regarding the status of nursing students and the pursuance of higher education among the hospital-based participants. The study was unique in that one of the three data collection sites was a university and the respondents may not have been actively practicing but may have been full-time students instead. This may account for the responses listed as "other" on the demographic forms.

In addition, the demographic data form also did not provide for participants to further specify choices of "other" for current level of practice, type of work unit, ethnicity, or religious preference. This limitation was especially noted among the variables of religion, where 47 participants (43.1\%) selected other as their response; current level of practice, where 21 participants (19.2\%) selected other as their response; and work unit, where 19 participants $(17.4 \%)$ selected other as their response. 
The demographic instrument only assessed the highest level of formal academic education. The completion of additional specialty certifications such as critical care, pediatric, or cardiac-related education, as determined by advanced certification, was not an educational factor elicited.

One significant weakness noted in the design of the knowledge base survey was question 8 which evaluated the nurses appropriate delivery of oxygen to the sickle cell patient. The question reads: "Oxygen therapy is usually ordered for sickle cell patients:", and the respondent is given four choices: (A.) in crisis, (B.) with complaints of chest pain, (C.) with a pO2 $75 \mathrm{~mm} \mathrm{Hg}$ or less, and (D.) all of the above. While the instrument creator (Lorenzi, 1993) has indicated that response (C.) "with a pO2 $75 \mathrm{~mm} \mathrm{Hg}$ or less" is the correct answer, none of the nurses in this sample correctly answered the question. All $(100 \%)$ of the survey respondents selected (D.) all of the above and may have been confused by the inclusion of chest pain as a symptom. One of the fundamental interventions for chest pain is oxygen delivery. Re-wording of the answer choices offered may have afforded a better response to this question. The study should be replicated with incorporation of the suggested modifications of the instruments.

4) The impact of SCD educational efforts can be studied by replication of the study using a test-retest structure with presentation of an SCD-specific training session. 


\section{REFERENCES}

Agency for Health Care Administration. (1994). Board of Nursing, Florida

Statutes: 464.

Anionwu, E. N. (1996). Sickle cell and Thalassaemia: Some priorities for Nursing research. Journal of Advanced Nursing, 23, 853-856.

Brookoff, D. (1992). A protocol for defusing sickle cell crisis. Emergency Medicine. 131-140.

Earles, A. (1989). Issues to be considered: an overview of legal issues.

Pediatrics, 83, (suppl.), 901-902

Eckman J. \& Platt, A. (1997). Sickle Cell Information Center Problem Oriented Clinical Protocols. Genetic Services branch of the Maternal and Child Health Bureau, U.S. Department of Health and Human Services (Grant MJC-131003-04).

Fitzpatrick, J. J. \& Whall, A. L. (1996). Conceptual Models of Nursing: analysis and application. Norwalk, CT: Appleton \& Lang.

Gribbons, D., Zahr, L.K., \& Opas, S.R. (1995). Nursing management of children with sickle cell disease: an update. Journal of Pediatric Nursing 10, (4), 232-242.

Hernandez, S. (1989). Social Work Perspective. Pediatrics, 83, (suppl.), 903-905.

Lisak, M. (1992). Sickle cell disease in: Jackson, P. \& Vessey (Eds.). Primary Care of the Child. St Louis, MO: Mosby Year Book.

Lorenzi, E. (1993). The effects of comprehensive guidelines for the care of sickle-cell patients in crisis on the nurses' knowledge base and satisfaction for care given. 
Journal of Advanced Nursing, 18, 1923-1930.

Martinelli, A. M. (1991). Sickle Cell Disease: Etiology, Symptoms, Patient Care. AORN Journal, 53, (3), 716-724.

Neuman, M. (1995). The Neuman Systems Model. (3rd Ed.). Norwalk, CT: Appleton \& Lang.

Nightingale, F. (1969). Notes on Nursing. New York: Dover Publications. Platt, A. (1997). Management and therapy of sickle cell disease. (National Institute of Health Publication no. 95-2117). Washington, DC: US Department of Health and Human Resources, Public Health Services.

Preiss, D. J. (1998). The young child with sickle cell disease primary management. Advance for Nurse Practitioners, 6, (6) 32-39.

Serjeant, G. R. (1997). Sickle cell disease. The Lancet, 350, 725-30.

Seleckman, J. (1993). Update: New guidelines for the treatment of infants with sickle cell disease Pediatric Nursing, 19, (6), 600-605.

Statistical Package for the Social Sciences, SPSS for Windows, Version 7.0. (1997). Chicago, IL: SPSS,

Webster's New World College Dictionary (1996). New York: Book Craft Guild. 3rd Ed.

Whitten, C. F. (1989). Perspective from the National Association for Sickle cell disease. Pediatrics, (Suppl.), 906-907

Woods, K. (1994). Sickle Cell Disease: Beyond the pain, A Comprehensive Approach to Care. Topics in Primary Care. 1-11. 


\section{APPENDIXES}




\section{APPENDIX A \\ Cover Letter}

Dear Colleague,

My name is Marie Etienne, RN, BSN. I am a graduate student at Florida International University in the MSN Program. I am conducting a study of nurses' knowledge level and attitudes towards patients with sickle cell disease (SCD) to meet the research requirements of the MSN program. I wish to invite you to participate in this study. Your participation is strictly voluntary and your identity will be protected and will remain anonymous. You may withdraw from the study at any time. You may refuse to participate by simply not completing or returning the questionnaire provided.

In order for you to participate in my study, you will need to return the completed questionnaire. Please seal the completed questionnaire in the envelope provided and place it in the box provided to you at the school or on your unit.

Please be aware that any data collected will only be used for statistical analyses. A summary of the research findings will be provided to you upon request. This study may enhance nurses'knowledge of sickle cell disease and lead to development of innovative nursing management of the patients with SCD. There are no known risks involved in studies like this. Thank you for your assistance and support. Sincerely,

Marie Etienne, RN, BSN

Graduate Nursing Student 


\section{APPENDCX B \\ KNOWLEDGE BASE INVENTORY}

Directions: Check the best answer for the following questions.

1. Sickle-cell patients should have a minimum daily intake of fluids:
a) $3 \mathrm{~L} /$ day
b) $5 L /$ day
c) $8 \mathrm{~L}$ day
d) no designated amount

2. The best choice of fluids to be encouraged for sickle-cell patients should be:
a) water, milk, orange juice
b) pop, juices, broth
c) coffee, tea, tomato juice

3. Vital signs, shortness of breath, dyspnea and new areas of pain in sickle-cell patients should be monitored in order to help detect:

a) infection and thrombosis

b) cerebral vascular accident and congestive heart failure

c) anemic crisis and infarction

d) all of the above

4. The classic form of sickle-cell disease called sickle-cell anemia is:
a) HbSS
b) $\mathrm{HbSC}$
c) HbAS

5. Sickle-cell anemia is a $(\mathbf{n})$ :
a) acquired disease
b) immune disorder
c) genetic disorder

6. The red blood cell lifespan in sickle cell anemia is:
a) 120 days
b) 90 days
c) 10-15 days
d) 45-60 days

7. The precipitating cause in up to $30 \%$ of cases of painful crisis is:
a) infection
b) dehydration
c) deoxygenation
d) acidosis 
8. Oxygen therapy is usually ordered for sickle-cell patients:
a) in crisis
b) with complaints of chest pain
c) with a pO2 $75 \mathrm{mmHg}$ or less
d) all of the above

9. Conservative therapy for pain constitutes:
a) no-narcotic medications
b) relaxation and distraction
c) bedrest
d) heat
e) all of the above

10. Frequent coping mechanisms used by the adult sickle-cell patient are:
a) repression
b) regression and displacement
c) projection and sublimation
d) all of the above

Direction: Mark $\mathrm{T}$ (true) or $\mathrm{F}$ (false) for the following questions.

1. It is necessary to record I \& O on sickle-cell patients in order to monitor for uremia and hypsthenuria.

2. The painful vaso-occlusive episode is the most common event in sickle-cell disease.

3. Haemophilus influenza is the usual causative organism of pneumonia in sickle-cell anemia patients.

4. It is necessary to record the colour and consistency of the urine of sickle-cell patients.

5. Emotional factors cannot precipitate a crisis.

6. Vessel occlusion can cause infarction in any organ of the body.

7. Priapism is not painful.

8. Sickle-cell patients are not at risk of developing hyponatraemia.

9. Patients in sickle-cell crisis can develop new areas of pain.

10. Gallstones are a common findings in sickle-cell anemia patients. 


\section{APPENDIX C}

\section{SICKL E CELL DISEASE ATTITUDE QUESTIONNAIRE}

\section{ATTTTUDES TOWARD NURSING CARE OF THE PATIENT WTTH SICKLE CELL DISEASE}

Please choose the letter which corresponds to your own personal feelings about the attitude presented. All statements concern the giving of nursing care to the patient with sickle cell disease. Please respond to all items on this scale.

1=Strongly Agree 2=Agree 3=Uncertain 4=Disagree 5= Strongly Disagree

1. Giving nursing care to patients with sickle cell disease is frustrating.

2. When giving nursing care I would be upset when a sickle cell patients press the call bell repeatedly.

3. I feel that sickle cell patients aren't really in pain when they say so.

4. I would purposely withhold pain medication because I believe sickle cell patients might become addicted to the pain medication.

5. I feel that sickle cell patients should receive placebo when they complain of pain

6. I treat all sickle cell patients like any other patient.

7. It is hard to form a close relationship with sickle cell patients.

8. I hope that I am not assigned to care for a sickle cell patient.

9. I think sickle cell patients are admitted in the hospital too frequently.

10. I seldom empathize with sickle cell patients and their families.

11. I am afraid to give nursing care to sickle cell patients because I think they are angry and violent patients.

12. The amount of time it takes to give nursing care and pain medication to the patients with sickle cell disease would frustrate me. 


\section{APPENDLX D}

\section{DEMOGRAPHIC NFORMATION}

Direction: Please circle your current age group and number of years in nursing.

1. What is your age?

Years of clinical nursing experience: $1 .<1$
2. $1-5$
3. $6-10$
4. 11-19
5. $>20$

3. Please circle your gender: 1. Female

2. Male

4. Please circle your highest level of education.
1. Diploma
2. $A D N$
3. BSN
4. MSN
5. Ph.D.

5. Please circle your current level of practice

1. Staff nurse

2. Assistant Nurse manager

3. Nurse Manager

4. Patient Care Coordinator

5. Other

6. Please circle what best describe your type of work unit.
1. Med-Surg
2. Telemetry
3. Pediatrics
4. Intensive Care
5. Emergency
6. Critical Care
7. Other
8. Combination

7. Please circle how you would best describe your ethnicity.
1. White NonHispanic
2. Black NonHispanic
3. Hispanic/Latino
4. Asian/Pacific Islander

5. Other 
8. Please circle your marital status.

1. Single

2. Married

3. Divorced/Separated

4. Widowed

5. Living with primary partner

9. Please circle your religious preference.

1. Catholic

2. Protestant

3. Jewish

4. Other 


\section{APPENDIX E}

\section{ANSWER KEY TO KNOWLEDGE BASE INVENTORY}

1. 2

2. b

3. d

4. a

5. c

6. $c$

7. 2

8. c

9. e

$10 . \mathrm{d}$

11. True

12. True

13. False

14. True

15. False

16. True

17. False

18. False

19. True

20. True 
19830 NE 14th Avenue

North Miami Beach, Florida 33179

(305) 652-0228

March 6, 1998

Northern Kentucky University

Department of Nursing

AHC 303

Nunn Drive, Highland Heights, Kentucky 41099

Mrs. Elizabeth A. Lorenzi

Assistant Professor of Nursing

Dear Mrs. Lorenzi:

My nme is Marie Osline Etienne, I am a graduate student at Florida International University. I am in the process of writing a master's thesis as a partial requirement for my degree of Master of Science in nursing.

I am writing this letter to ask for your permission to use your tool on knowledge base inventory for my research. I found your tool in the article that was published in Journal of Advanced Nursing, 1993, 18, p. 1923-1930. the title of your article was "The effects of comprehensive guidelines for the care of sickle-cell patients in crisis on the nurses' knowledge base and job satisfaction for the care given". My research topic is "An assessment of nurses" knowledge and attitudes toward patients with sickle cell disease".

Please let me known as soon as you can so I can proceed with my research. I would also like to ask you for copy rights of the materials. Your cooperation and assistance in this project mean so much to me.

Thank you in advance for your time.

Sincerely yours,

Marie O. Etiennè, RN,BSN

Graduate Student 
March 25, 1998

747 Barney Ave.

Wyoming, Ohio 45215

Marie Etienne

19830 N.E. $14^{\text {th }}$ Ave.

North Miami Beach, FI. 33179

Dear Marie,

I have enclosed a copy of the answers to the Knowledge Base Inventory Tool. You have my permission to use the tool in you research project. You also have my permission to make copies of the tool for use in your research. I ask that you disseminate any new findings to me. Good luck with your research.

Sincerely,

Elizabeth A. Lorenzi, MSN, RN 
Directions. : Check the best answer for the following questions.

1. Sickle cell patients should have a minimum daily intake of:
a. $3 \mathrm{~L} / \mathrm{day}$
b. $5 \mathrm{~L} / \mathrm{day}$
c. $8 L /$ day
d. no designated amount

2. The best choice of fluids to be encouraged for sickle cel patients should bo :

a. water, milk, orange juice

๖. pop, juice, broth

c. coffee, toa, tomato juice

3. Vital signs, sOB, dyspnea, and new areas of pain in sickle cel patients should bo monitored in order to belp detect :

$\begin{array}{ll} & \text { a. infection and thrombosis } \\ = & \text { b. cVA and CHF } \\ & \text { c. anemic crisis and infarction } \\ & \text { d. all of the above }\end{array}$

4. The classic from of sickle cell disease called sickle cel anemia is:

$\mathcal{L}$ a. $\mathrm{Hbss}$

5. Sickle cell anemia is a $(n)$ :

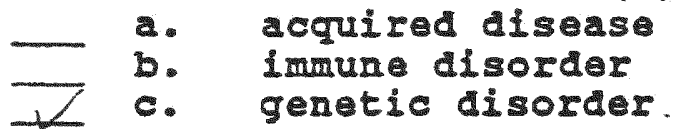

6. The RBC Iifespan in sickle cell anemia is:

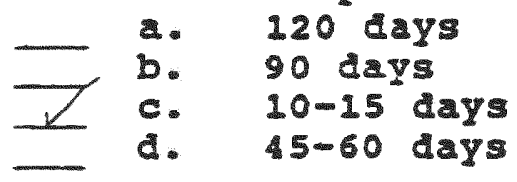

7. The precipitating cause in up to 30 \% cases of painful crisi $\begin{array}{ll}\text { is: } & \\ \text { a. } & \text { infection } \\ \text { b. dehydration } \\ \text { c. deorygenation } \\ \text { d. acidosis }\end{array}$ 
8. Oxygen therapy is usually ordered for sickle cell patients: - b. in crisis

$\checkmark$ c. with a po2 75 . ming or less

a. all of the above

9. Conservative therapy for pain constitutes:

a. non-narcotic medications
b. relaxation and distraction
c. bedrest
d. heat
a. all of the above

10. Frequent coping mechanisms used by the adult sickle cell patie are:

$\begin{array}{ll} & \text { a. } \\ \text { b. repression demial } \\ \text { b. projession displacement } \\ \text { ¿ .. all of the above }\end{array}$

Directions: Mark $T$ (True) or $F$ (False) for the following grestion

$T$ 1. It is necessary to record I \& o on sickle cell patients order to monitor for uremia and hyposthenuria.

I 2. The painful vaso-ocelusive episode is the most common eve in siekle cell disease.

3. Hemophilus influenza is the usual causative organism pneumonia ia sickle cell anemia patients.

T 4. It is necessary to record the color and consistency of $t$ urine of siekle cell patients.

5. Emotional factors cannot precipitate a crisis.

6. Vessel occlusion can cause infarction in any organ of $t$ : body.

7. Eriapism is not paineul

8. sickle cell patients are not at risk of developir hyponatremia.

9. Patients in sickle cell crisis can develop new areas! pain.

10. Gall stones are common finding in sickle cell aners patients. 


\section{FLORIDA INTERNATIONAL UNIVERSTTY COLLEGE OF HEALTH SCIENCES}

An Assessment of nurses' knowledge and attitudes toward patients with sickle cell disease

May 4, 1998

Dear Sir/Madam:

I am a Master of Science candidate in the Dept. of Nursing at FIU. I am conducting a research study as a partial requirement toward the completion of a Master's Degree in Nursing. The study is focused on Assessing nurses' knowledge level and attitudes toward patients with sickle cell disease. I am requesting permission to use your facility to recruit prospective participants for my study. Information gained from this study may enhance nurses' knowledge and their attitudes toward patients with sickle cell disease may be improved. Also, as the result of the study in the future, nurses will be more knowledgeable of sickle cell disease and will have a more positive attitude when caring for these patients.

Continuing education about sickle cell disease will better prepare nurses to care for patients with sickle cell disease. The prospective candidates will be informed that the study is strictly voluntary, and refusal will not jeopardize their jobs in any way.

The questionnaire will be given to the participants with an envelope to be sealed by them. Data collection in the study will be handled only by the principal investigator, the faculty Supervisor, and the statistician. The raw research data will be kept in a securely locked box.

Thank you in advance for your help and consideration.

Sincerely,

Marie O. Etienne, RN, BSN 


\section{Florida International University}

June 15,1998

Ms. Mary Osline Etienne

(Dr. Luz Porter)

AC 203

Florida International University

North Miami Campus

North Miami F1 33181

Dear Ms. Etienne:

I am pleased to inform you that your research proposal titled "An Assessment of Nurses' Knowledge and Attitudes Toward Patients with Sickle Cell Disease" has been reviewed and approved. Please note that you are required to conduct your research and all related procedures in the exact same manner as indicated in the proposal without any exception. I wish you all the best.

Sincerely

Suman Kakar, Ph.D.

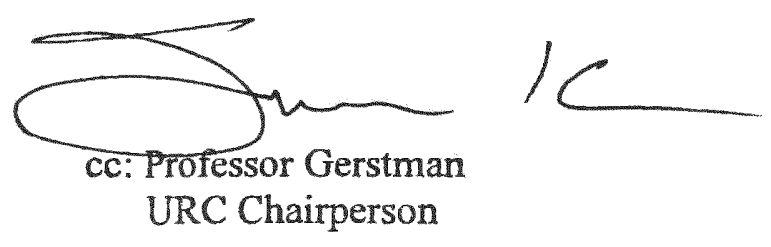




\section{MEDICAL CENTER \\ NURSING ADMINISTRATION}

An Assessment of nurses' knowledge and attitudes toward patients with sickle cell disease

May 4, 1998

Dear Sir/Madam:

I am a Master of Science candidate in the Dept, of Nursing at FIU. I am conducting a research study as a partial requirement toward the completion of a Master's Degree in Nursing. The study is focused on Assessing nurses' knowledge level and attitudes toward patients with sickle cell disease. I am requesting permission to use your facility to recruit prospective participants for my study. Information gained from this study may enhance nurses' knowledge and their attitudes toward patients with sickle cell disease may be improved. Also, as the result of the study in the future, nurses will be more knowledgesble of sickle cell disease and will have a more positive attitude when caring for these patients. Continuing education about sickle cell disease will better prepare nurses to care for patients with sickle cell disease. The prospective candidates will be informed that the study is strictly voluntary, and refusal will not jeopardize their jobs in any way.

The questionnaire will be given to the participants with an envelope to be sealed by them. Data collection in the study will be handled only by the principal investigator, the faculty Supervisor, and the statistician. The raw research data will be kept in a securely locked box.

Thank you in advance for your help and consideration.

Sincerely,

$\frac{\text { Conce Q. Etuive, RuBSD }}{\text { Marie O. Etienne, RN, BSN }}$ 
July 6, 1998

Marie Etienne, $R N$

Medical Center

Dear Marie:

This letter serves as authorization to proceed with your research study here at Medical Center.

It is understood that $\mathrm{RN}$ staff in the Medical Surgical and Critical Care areas will be invited to participate and their participation is strictly voluntary and anonymous.

The focus of your study is very applicable to our practice of nursing. I request a summary of your research findings. I would also be interested in discussing the potential for future inservice programs related to this study.

Sincerely,

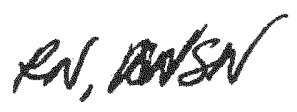

Vice President-Patient Care

/sdr 
LETTER REQUESTING USE OF A FACILITY FOR DATA COLLECTION

\section{REGIONAL MEDICAL CENTER NURSING ADMINISTRATION}

An Assessment of nurses' knowledge and attitudes toward patients with sickle cell disease

JULY 29, 1998

Dear Sir/Madam:

My name is Marie Etienne, RN, BSN. I am a graduate student at Florida International University. I am conducting a research study as a partial requirement toward the completion of a Master's Degree in Nursing. The study is focused on assessing nurses' knowledge level and attitudes toward patients with sickle cell disease (SCD). I am requesting permission to use your facility to recruit prospective participants for my study. Inform ation derived from this study may enhance nurses' knowledge about SCD and their attitudes toward patients with sickle cell disease may be improved. Continuing education about sickle cell disease will better prepare nurses to care for patients with sickle cell disease. The prospective subjects will be informed that the study is strictly voluntary, and refusal will not affect their grades in any way.

The questionnaire will be given to the participants with an envelope to be sealed by them. Data collection in the study will be handled only by the principal investigator. The raw research data will be kept securely for 3 years.

Thank you in advance for your help and consideration.

Sincerely,

Darie Q. Eture.euBse

Marie O. Etienne, $\mathbb{R N}, \mathbf{B S N}$ 
September 11, 1998

Marie O. Etienne

19830 N.E. 14th Avenue

North Miami Beach, Florida 33179

Dear Ms. Etienne,

I have reviewed your research proposal on assessment of nurses' knowledge and attitudes toward patients with sickle cell disease. On behalf of 'Regional Medical Center I am pleased to inform you that we have agreed to allow you to conduct your research at our facility. I understand that confidentiality and anonymity will be maintained throughout your study.

Please provide me with the exact date(s) and time(s) you will be conducting your study in our facility.

Good luck in your professional endeavors.

Sincerely,

Director, Health \& Safety Management

cc: $\therefore$ Chief Administrative Officer

- Director, Medical/Surgical Nursing

Education Coordinator 


\section{FLORIDA INTERNATIONAL UNIVERSITY \\ UNIVERSITY RESEARCH COUNCIL (URC)}

\section{APPLICATION FOR APPROVAL OF RESEARCH INVOLVING HUMAN SURJECTS}

1. PROJECT TITLE: An assessment of nurses' knowledge and attitudes toward patients with sickle cell disease

2. PRINCIPAL INVESTIGATOR: Marie Osline Etienne SSH: Address: 19830 NE 14th Avenue, North Miami Beach, Florida $3317 y$ Phone: (305) 652-0228

Position: () Faculty (X) Graduate Student () Undergraduate () Other

3. FACULTY SUPERVISOR: Luz S. Porter, Ph.D., ARNP, Professor

4. STATUS OF PROJECT REVIEW:

(X) New project () Revision of previously approved project

() Continuation of approved project

5. BRIET DESCRIPTION OF SUBJECTS:

Number of subjects: Minimum of approximately 100

Check all of the following categories that describe your research subjects:

(X) Males

(X) Females

( ) Minors (under 18 years of age)

(X) Students (Please specify): Undergraduate and/or Graduate nursing students

( ) Persons With Physical Disabilities (Please specify):

( ) Persons With Mental/Psychological Disabilities (Please Specify):

( ) Persons With Physical or Mental Health Problems (Please Specify):

( ) Persons With No Known Disabilities and No Known Health Problems

() Prisoners

( ) Pregnant women, fetuses, fetal material or placenta (Please Specify):

( ) Persons In Some Type of Program (Please Specify):

(X) Other Pertinent Information (Please Specify): Registered nurses working in acute care settings.

6. TYPE OF REVIEW REQUESTED:

( ) Exempt: Category \# (s):

(X) Expedited Review : Category 9

( ) Full URC Review (Can neither Exempted of Expedited) 
7. RESEARCH OBJECTIVES: The overall objectives for this study are:
A. To examine nurses' knowledge level of sickle cell disease.
B. To determine the relationship between nurses' knowledge of sickle cell disease and their attitudes toward patients with sickle cell disease.
C. To examine the relationship between demographic variables and nurses" attitude toward patients with sickle cell disease.

\section{SUBNECTS RECRUTMMENT:}

A. The sample will consist of approximately 100 Registered Nurses. The population will include those who are currently working in acute care setting and those who are currently attending undergraduate and or, graduate school of nursing.

B. The principal investigator will also recruit subjects from North Shore Medical Center, Parkway Regional Medical Center, Florida Intermational University. The principal investigator will ask permission to use graduate students in their last semester. The principal investigator will approach subjects and establish eligibility for participation in the study.

Potential subjects will be given an overview of the study indicating that (1) participation is strictly voluntary, (2) responses to questionnaires will not be identified with any study participant, (3) refusal to participate in the study will not affect participants' employment status, performance evaluation or grades in school.

\section{BENEFITS:}

A. There are no specific benefits that might gained from participation in the the study. However, information derived from this study may change nurses' attitude toward sickle cell disease patients and may broaden their knowledge of sickle cell disease. Nurses' knowledge of sickle cell anemia may be enhanced and their attitudes toward patients with sickle cell may be further improved. Increased knowledge and positive attitudes toward patients with sickle cell disease might improve care given to those clients.

\section{INFORMED CONSENT:}

A. Questionnaires that are completed will indicate consent for participation in the study.

B. Participants will be given an overview of the study and will also be told that participating in the study will be strictly voluntary. Participants may refuse to participate and that their refusal will not penalize them in 
anyway. Subjects will be given the telephone number of the principal investigator and major professor to call if they have any questions related to the study.

\section{CONFDENTIALITY OF DATA:}
A. All data collected will be handled only by the principal investigator, the major professor, and the statistician.
B. Completed questionnaires forms will be kept securely in the principal investigator's office at home in a locked filing cabinet for 3 years.
C. Written and verbal instructions will describe how confidentiality and anonymity of data will be maintained on the questionnaire.
D. Findings from data collected will be summarized and individual participants will not be identified in any way.

\section{METHOD AND PROCEDURES:}
A. Approval of the research protocol and permission to conduct the study will be obtained from FIU-IRB, and administrators of the hospital chosen. Then data will be conectea from petential subjects.
B. A sealed box will be provided to drop off completed questionnaires.
C. Confidentiality of data will be protected as described in iten 11 .
D. Participants will be informed that they may withdraw from the research study at anytime time without harm or penalties. Recruitment of subjects will be done as indicated in Item \#8.
E. Questionnaires will be given to participants. A separate envelope will be given to subjects for completed questionnaires placement which will be sealed by the participants themselves, and will be locked at the principal investigators" office for 3 years.

\section{STIMUUUS MATERIALS:}

A. Knowledge Base Inventory is a 20 item questionnaire. This questionnaire was developed by Elizabeth Lorenzi in 1993. She developed the tool to identify the knowledge base of nurse when giving care to patients with sickle cell disease. Content validity and reliability were established for the Knowledge Base Inventory tool (Spearman Brown reliability coefficient $=0.77$ ).

B. Sickle Cell Disease Attitude questionnaire is a 12 item in a likert scale designed by the principal investigator to measure nurses' attitudes toward patients with sickle cell disease. The attitude questionnaire will be tested for validity (face and content) and reliability prior to actual data collection.

C. See appendix Cfor Demographic information. 
14. RISKS TU SUBJECTS: This study is strictly voluntary for subjects to participate. There may be some anxieties involved which are no greater than those faced in normal daily life. Participants will be informed to call the principal investigator for any questions related to the study. 


\section{AFFIRMATION OF COMPLIANCE AND ACCEPTANCE OF RESPONSIBUTTY}

I agree to follow the procedures outlined in this summary description and any attachments. I understand that no contact may be initiated with subjects until I have received approval from the URC and have complied with any modifications required in connection with that approval. I understand that additions to or changes in the procedures involving human subjects can only be made after approval of the URC. I understand that I must promptly report to the URC any problems with the rights or welfare of the human subjects. I understand and will follow Florida International University's policies concerning research with human subjects. I will do everything in my power to protect the rights and welfare of human subjects in my research project.

\section{AN ASSESSMENT OF NURSES' KNO WLEDGE LEVEL AND ATTUTUDES TOWARD PATIENTS WITH SICKLE CELL DISEASE}

(Title of Project)

Mavie (elive Estiene)

Signature of Principal Investigator

Macie Csline Etienae

Printed Name of Principal Investigator

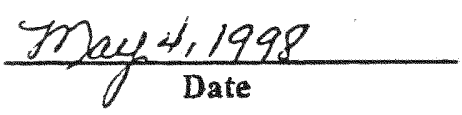

I have read this application and assume responsibility for its accuracy and for supervision of the proposed project.
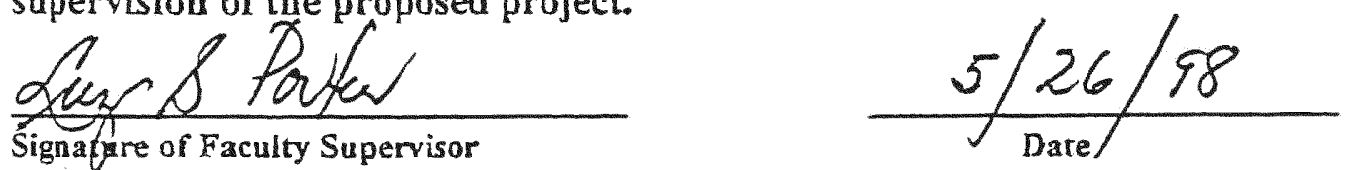

ACTION RECOMMENDED BY URC **FOR URC use only**

Date: (X) Expedited Review () Approved

() Require Full Board Review

() Changes/Clarifications Requested

Signature of URC Chairperson

Printed name of URC Chairperson

Date: ( ) Approved ( ) Changes/Clarifications Requested ( ) Require Full Board Keview 